\title{
Research on the Consumer Finance System of Ant Financial Service Group
}

\author{
Yanan Zhao \\ College of Economics, Jinan University, Guangzhou, China \\ Email: zhaoyanan.grace@foxmail.com
}

How to cite this paper: Zhao, Y.N. (2017) Research on the Consumer Finance System of Ant Financial Service Group. American Journal of Industrial and Business Management, 7, 559-565.

https://doi.org/10.4236/ajibm.2017.75041

Received: March 24, 2017

Accepted: May 13, 2017

Published: May 16, 2017

Copyright $\odot 2017$ by author and Scientific Research Publishing Inc. This work is licensed under the Creative Commons Attribution International License (CC BY 4.0).

http://creativecommons.org/licenses/by/4.0/

\begin{abstract}
This paper takes the Ant Financial Service Group as an example and analyzes the development pattern of its consumer finance system. The Ant Financial Service Group developed from an e-commerce platform. Its consumer finance system takes full advantages of the large amount of data which is accumulated from the e-commerce platform. This kind of development mode can realize the win-win development of e-commerce platform and Internet consumer finance, which has the reference significance to the development of other consumer finance platforms.
\end{abstract}

\section{Keywords}

Consumer Finance, E-Commerce Platform, Consumption Stickiness, Credit System

\section{Introduction}

Consumer finance refers to the financial services provided to meet the needs of residents for goods and services, which is essentially an intertemporal consumption model where consumers get rid of the liquidity constraints of immediate consumption and get more goods and services in a certain period of time [1]. It includes mortgage, car loans, credit card installments and so on which are provided by the traditional commercial banks. Additionally, the "Internet consumer finance" which is the combination of Internet and consumer finance has also got rapid development in recent years.

Alibaba Group and Jingdong Group have started their own consumer credit business with their data advantages to expand their financial business, and strive to gain a foothold in the important strategy of consumer finance. In their own electricity business circle, the amount of credit sales is provided to consumers, so that consumers can pay installment with a certain fee. This paper chooses a rep- 
resentative group whose name is Ant Financial Services Group in this field and tries to analyze its business and the relationship between the various businesses in order to explore the construction of its consumer finance system. Ant Financial Services Group was formally established in October 2014, focusing on serving small micro-enterprises and ordinary consumers. Its financial products include Alipay, Yu'ebao, Zhaocaibao, Zhima Credit, Ant check later and so on.

This paper is divided into five parts. The first part is the introduction which mainly introduces the research background. The second part mainly elaborates the consumption financial system of the Ant Financial Services Group and specifically analyzes how can Alipay, Yu'ebao and Zhaocaibao attract consumers and realize the accumulation of consumers' information. The third part introduces Zhima Credit. The fourth part introduces a consumption financial product which called Ant Check Later Loan. The last part summarizes the whole paper.

\section{Consumption Stickiness and Consumer Stickiness}

\subsection{Alipay and Consumption Stickiness}

\subsubsection{Introduction to Alipay}

Alipay (China) Network Technology Co., Ltd. (hereinafter referred to as Alipay) was established in December 2004, which is one of China's mainstream thirdparty network payment platforms. At the beginning of its establishment, the company's main purpose is providing credit guarantee on both sides who involve in trading on an E-commerce website which called Taobao. In this way, the problem about trust and payment that has plagued the development of ecommerce market can be solved. According to the data which is publiced by Taobao, the transaction value of Taobao in 2003 is about 20 million. But after the introduction of Alipay, the transaction value in 2004 rose rapidly to 1 billion yuan and reached 80 billion yuan in 2005.As of November 30, 2012, the transaction value exceeded 1 trillion yuan.

\subsubsection{The Service Coverage of Alipay}

Ants Financial Services Group set up in October 2014, and its predecessor is Alipay company. Alipay changed its positioning of a single third-party payment platform in the past, and aims to build a real-name and trust-based one-stop scenario platform to meet the users' demand in consumption, financial management, urban life, communication and so on.

Alipay works with more than 200 financial institutions to serve nearly 10 million consumers and small companies. Alipay covers the vast majority of online consumption scenarios, and also vigorously expand the various offline scenes, including taxis, public transport, supermarkets, convenience stores and restaurants. More than 130,000 Offline shops and more than 500,000 taxi cars has supported the use of Alipay.

Alipay is also accelerating the expansion of international business. More than 30 countries and regions, and nearly 2000 signed merchants have supported the 
use of Alipay.

In the field of financial management, Alipay's users can buy Yu'ebao, Zhaocaibao, stocks and other financial products. The number of users who use Alipay to manage their finances has reached more than 200 million.

In July 2015, Alipay added a kind of function called "friends" which can meet the users' need of communication.

\subsubsection{Innovation of Alipay's Payment Method}

Alipay provides users with the following two payment methods:

One is that Alipay plays the role of intermediary guarantee in online shopping transactions [2]. Take an example of Taobao C2C transactions, the transaction process in which Alipay is used can generally divided into six steps:

(1) After a customer has decided what they want to buy, they can issue a purchase order to the seller;

(2) The customer chooses Alipay as a trading intermediary, and then pays the corresponding payment to his Alipay account;

(3) Alipay notices the seller that the customer has paid and reminds the seller to ship on time;

(4) After receiving Alipay's notice, the seller deliveries merchandises to the customer;

(5) After the customer received the goods, he tells Alipay that he has got the goods;

(6) Alipay takes the payment into the seller's account. Then the transaction is completed.

This kind of payment method can reduce the degree of information asymmetry between buyers and sellers and can help to accelerate the process of Internet financial transaction.

The other is to pay instantly [2]. The process is very simple, that is the buyer directly pays the money to the seller in the use of Alipay. This feature extends Alipay's service range. It can not only provide payment services to Taobao users, but also provide payment services for buyers and sellers to reach other offline transactions. For example, many of the $\mathrm{P} 2 \mathrm{P}$ network borrowing platforms choose Alipay as a borrower and lender's third-party payment tool.

For the Internet finance, the account is the world, and the account sticky determines the market share. Alipay is the leader of Internet financial payment. Its service content, service convenience and service innovation are the main aspects to attract customers. On the one hand, these customers' massive trading data can help the Ant Financial Service Group to build a credit system. On the other hand, these customers can become the potential customers of the credit system.

\subsection{Yu'ebao, Zhaocaibao and Customer Stickiness}

\subsubsection{Yu'ebao and Customer Stickiness}

In June 17, 2013, Yu'ebao emerges. It is a new account balance value-added service. In this service, users of Alipay can transfer their money from Alipay account to Yu'ebao account . This behavior means that the users of Alipay agree to 
buy the fund products of Tian Hong Fund Company. Then the fund company will raise the funds to invest, and pay a certain amount of interest to the users of Yu'ebao. In the meanwhile, the money in Yu'ebao account can be used at any time in online shopping and other payment.

Because Alibaba's electricity business platform and Alipay network has accumulated a huge amount of customers and huge amount of idle funds, the access of Yu'ebao greatly caters to the needs of the market. Only 5 months later, the number of its users reached 81 million. Yu'ebao is actually the product of Alipay's development. It makes up for a defect in Alipay [3]. The defect is that money in Alipay account cannot bring interest to the users of Alipay. So the emergence of Yu'ebao increases the customer stickiness of Ant Financial Service Group.

\subsubsection{Zhaocaibao and Customer Stickiness}

Zhaocaibao appears in April 2014. All kinds of financial institutions such as banks, insurance companies and fund companies can show their financial products on the platform of Zhaocaibao [4]. And the users of Zhaocaibao can choose what they like.

Although Yu'ebao can solve the problem of monetary funds, it cannot meet all the needs of customers. Some users of Yu'ebao are willing to accept more risk and gain more interest. So Zhaocaibao meets their needs. On the basis of Yu'ebao, Zhaocaibao further enhances the customer stickiness of Ant Financial Service Group.

Overall, Alipay can provide great convenience to customers who buy goods on Taobao. Yu'ebao and Zhaocaibao can meet the customers' demand of financial management. The consumer for the purpose of consumption can through Alipay use Yu'ebao and Zhaocaibao to manage their money, and the users of Yu'ebao and Zhaocaibao can through Alipay to buy goods on Tobao and other E-commerce platform. On the whole, Alipay, Yu'ebao and Zhaocaibao can increases the consumption stickiness and the customer stickiness of Ant Financial Service Group.

\section{Establishment of Credit System}

On January 28, 2015, Ant Financial Services Group's “Zhima Credit Management Co., Ltd." tested their personal credit system for the first time.

\subsection{Data Source of Zhima Credit}

The data sources of Zhima Credit include three aspects: the first is the data within the Ali system; the second is the data provided by external cooperation agencies; the third is the user self-submitted information data [5].

Alibaba has Taobao, Tianmao and other business platform and Ants Internet Financial Service platform and its business began to deep into the water and electricity coal charges, taxi, medical and other fields. So it has accumulated a large amount of data. These dates are different from the traditional credit data 
which are mainly come from the field of borrowing. They covers the credit card repayment, online shopping, transfer, finance, Rental information, address relocation history, social relations and other aspects [6].

External data includes the information of user's income, deposits, securities, commercial insurance, real estate information and taxable amounts.

Users can also provide their "academic status", "unit mailbox", "vehicle information" to complete their personal information.

\subsection{Zhima Score}

Zhima Credit established personal credit dimension with reference to the famous American credit agency FICO. Specifically, Zhima Credit use five dimensions: the users' credit history, behavior preferences, performance, identity characteristics and personal connections [7]. In the future, the user's record of public interest behavior will be included in the assessment of Zhima Credit.

On this basis, the user's credit score which is called Zhima Score is divided into five levels. The score range is 350 to 390 and the higher the score, the higher the credit level [8].

\subsection{Business Progress}

At present, Zhima Credit is not only used in Ali Group, but also used in daily life services, P2P lending and traditional financial sector [9].

Users whose Zhima Score is more than 600 can apply for "Ant Check Later" consumer loans (up to 3 million) which can used in Taobao shopping payment.

Silver Lake Network and Zhima Credit has reached a strategic cooperation agreement. According to the agreement, Silver Lake Network can use Zhima Score to evaluate the borrower's credit.

Users of Zhima Credit can apply for Singapore and Luxembourg visas with "Zhinma Score" and "Sesame Credit Report" (Singapore visa needs 700 points and Luxembourg visa needs 750 points) without having to submit additional information such as proof of assets, proof of employment and so on.

Beijing Bank and Zhima Credit signed a strategic cooperation agreement and Beijing Bank became the first cooperative bank with Zhima Credit. The two sides will carry out credit information inquiry and application, product development, business activities and other aspects of cooperation.

\subsection{Development Outlook}

The Ant Financial Service Group's financial services which are involved in the lending business are inseparable from the credit information [10]. Therefore, the introduction of Zhima Credit can play an important supporting role in the smooth development of other financial services.

So far, Zhima Credit has started cooperation with relevant agencies in the field of daily life, consumption, P2P network loans and the traditional financial sector. If Zhima Credit can be recognized in a wide range of areas, it will become a huge measurable and achievable asset for Ant Financial Service Group. At the 
same time, consumers will pay more attention to their Zhima Credit. If consumers want to increase their "Zhima Score", they will purchase more goods and services on Ali's E-commerce platform and Ant Financial Service Internet platform. So not only the original Ali users will increased their dependency on Ali, but also more new users will be attracted. In addition, Zhima Credit can form a constraint to regulate the user's consumption behavior and lending behavior, which will indirectly reduce the cost of Ali.

\section{Consumer Financial Product-Ant Check Later Loan}

On December 27, 2014, Ant Financial Service Group launched a new credit service called Ant Check Later. It means that the network credit consumption is formally incorporated into the Ant Financial Service Group's financial system.

Ant Check Later loan is a kind of loan service which is provided to a consumer who has an Alipay account and the loan is limited to consumption use [11]. The lender can use the loan to purchase the goods or services which are approved by the service provider. The application, use and termination of this service must be completed by designated Alipay account. The maximum amount of the loan is 30,000 yuan and the longest interest-free period is 50 days.

The consumers can choose non-scheduled repayment services and installment repayment services. And a certain percentage of the installment fee will be charged. According to the number of stages of repayment, the percentage of the installment fee is different.

The repayment sources are limited to Alipay account balance, debit card account balance and the balance of wealth management products such as noncredit funds. The way of repayment is divided into active repayment and automatic repayment. If the consumer chooses the way of automatic repayment, he can set the repayment order between Alipay account and other accounts. At the same time, Ant Check Later Loan has the right to monitor and manage the source of repayment funds.

Ant Check Later Loan can promote consumers to buy more goods and services in the Ali e-commerce platform [12]. And more consumers' date will be provided to Ant Financial Service Group. These dates can help Ant Financial Service Group to provide more financial services to meet the financial demand of consumers. This is a virtuous circle.

\section{Conclusion}

This paper takes the consumption financial system of Ant Financial Service Group which developed from an e-commerce platform as an example to analyze the development pattern of its consumer finance, and finds that the whole industry chain is completely owned by Ant Financial Service Group. This kind of pattern can minimize the transaction costs and the risk which caused by information asymmetry, and can maximize the consolidation and training of customer base. Then a large number of transaction data can be accessed. Using these data can help to design credit products which can bring revenue. This kind 
of development mode can realize the win-win development of e-commerce platform and Internet finance, which has the reference significance to the development of other consumer finance platforms.

\section{References}

[1] Wei, J. (2015) Consumer Finance: Innovation and Development. First-Line Topic, 11, 96-99.

[2] Chen, J. (2014) Research on the Internet Financial Innovation-Based on Alipay. E-Commerce, 2, 63-65.

[3] Zhang, J. and Chen, L.Z. (2015) Research on the Service Model's Innovation of Yu'ebao. Chinese Soft Science, 2, 57-64.

[4] Li, Q. (2014) A New Platform for Financial Management-Zhaocaibao. Zhe Jiang Daily, August 26 2014, 11.

[5] Huang, K. (2015) Zhiama Credit Access Consumer Finance. 21st Century Business Herald, April 9 2015, 19.

[6] Hua, M.F. (2015) Zhiama Credit Open: The Door of Large Data Credit System. 21st Century Business Herald, January 30 2015, 20.

[7] Guan, J. (2015) Zhima Credit Enter Personal Credit Market. First Daily of Finance, January 29 2015, A11.

[8] Lu, Y.F. (2015) Small Sesame and Big Ambition. New Economy, 9, 54-55.

[9] Lu, L.Y. (2015) Zhima Credit Test Consumer Financial System. Communication Information, April 15 2015, B12.

[10] Jing, X.D. (2015) Internet + Large Data Credit. 21st Century Business Herald, May $132015,16$.

[11] Qian, H.L. (2015) Ant Check Later on the Line. Computer and Network, 1, 10.

[12] Yang, T. (2015) Innovation and Development of Consumer Finance in Internet Era. Zhejiang Economy, 13, 16-17.

Submit or recommend next manuscript to SCIRP and we will provide best service for you:

Accepting pre-submission inquiries through Email, Facebook, LinkedIn, Twitter, etc. A wide selection of journals (inclusive of 9 subjects, more than 200 journals)

Providing 24-hour high-quality service

User-friendly online submission system

Fair and swift peer-review system

Efficient typesetting and proofreading procedure

Display of the result of downloads and visits, as well as the number of cited articles

Maximum dissemination of your research work

Submit your manuscript at: http://papersubmission.scirp.org/

Or contact ajibm@scirp.org 